\title{
SOB A LENTE DA MEMÓRIA: RETRATOS DE FAMÍlIA EM Estátua de sal de Maria Ondina Braga ${ }^{1}$
}

UNDER THE LENT OF THE MEMORY: FAMILY PORTRAITURE in Statue of salt by Maria Ondina Braga

Dora Nunes Gago

Universidade de Macau

Macau, China

\section{Resumo}

Este artigo explora os "álbuns de família" delineados na obra de teor autobiográfico intitulada Estátua de Sal da escritora portuguesa Maria Ondina Braga. Atendendo aos pressupostos teóricos de Anne Muxel, Halbwachs, Candau, entre outros, o nosso objectivo será analisar, numa óptica comparativista, os "álbuns" das famílias britânicas com quem a autora viveu como au pair e as representaçóes da sua própria família, evidenciando o modo como o olhar face ao outro, à realidade estrangeira e à transmissão da memória cultural se assumem como instrumentos definidores da identidade no seio da alteridade.

Palavras-chave: memória; família; identidade; alteridade; britânicas.

\section{Abstract}

This article explores the "family albums" drawn in the portuguese writer Maria Ondina Braga's autobiographical work entitled Estátua de Sal (Statue of Salt). Based on the theories of Anne Muxel, Halbwachs and Candau, among others, our aim is to analyze, comparatively, the "albums" of the British families with whom the author lived as an au pair, and the representations of her own family. We will show how viewing the "other", the foreign reality and the transmission of cultural memory is a tool to define identity within alterity.

Keywords: memory; family; identity; alterity; british.

\section{Resumen}

Este artículo explora los álbumes de familia dibujados en la obra de corte autobiográfico titulada Estátua de Sal de la escritora portuguesa Maria Ondina Braga. Bajo los presupuestos teóricos de Anne Muxel, Halbwachs y Candau, entre otros, nuestro objectivo es analizar, en una óptica comparativista, los álbumes de las familias británicas con quiénes la autora vivió y trabajó y las representaciones de sua propia familia evidenciando el modo cómo la mirada hacia el otro, hacia la realidad extranjera y la transmisión de la memoria cultural, se asumen como herramientas definidoras de la identidad en el seno de la alteridad.

Palabras-clave: memoria; familia; identidad; alteridad; británicas. 
Sob a lente da memória, Maria Ondina Braga evoca na obra Estátua de Sal, escrita em Macau em 1963, as suas vivências passadas, desde o tempo da sua infância na cidade de Braga, no norte de Portugal, passando por todos os países onde viveu, desde Inglaterra, França, Índia, Angola e, por fim, Macau. Este percurso rememorativo deixa transparecer a busca de uma identidade tão fragmentada e dispersa como as próprias memórias. Para além da tentativa de reconstrução de identidade, da transmissão da memória, é também um sentido de pertença que a narradora procura, na linha de pensamento de Assmann (2010) que salienta a pertinência do acto narrativo como alicerce do estabelecimento das noçóes de pertença ou de identidade, de conexão do "eu" ao "outro" enraizada no vínculo de regras e valores comuns. No fundo, nesta autobiografia romanceada, revela-se o desejo de um encontro do "eu" consigo próprio, numa tentativa de reunir os retalhos e memórias fragmentadas e dispersas da sua existência pelo mundo e pela vida (GAGO, 2016: 1). Aliás, este acto rememorativo corresponde a um "olhar para trás, assumindo o risco da transformação em "estátua de sal", como sucede com a mulher de Lot (Génesis, 19: 26).

Em Estátua de Sal, encontramos um narrador autodiegético, que espelha a figura da autora empírica, surgindo, por isso, "como entidade colocada num tempo ulterior em relação à história que relata, entendida como conjunto de eventos concluídos e inteiramente conhecidos" (REIS \& LOPES, 1991: 260).

Com efeito, Maria Ondina Braga percorreu variados territórios de exílio e ficou órfã muito cedo. Curiosamente, esta situaçáo de orfandade prematura permitiu-lhe viajar pelo mundo sem necessitar da autorização do pai (já falecido) ou de um marido, visto ter permanecido solteira. Caberia esclarecer que durante o período ditatorial português denominado de Estado Novo - instituído sob a direção de António Oliveira Salazar e que vigorou entre 1933 e 1974 - as mulheres necessitavam da autorização do pai ou do marido para saírem de Portugal.

O trabalho como au pair, em meados dos anos cinquenta, em Inglaterra, possibilitou a Maria Ondina Braga a vivência com uma família inglesa e uma família escocesa de cujas crianças cuidava. No conto "Lua de sangue", que integra a colectânea com o mesmo título, umas das personagens, Inês, que regressa a Portugal e que é de certo modo um duplo da autora, quando é questionada pela prima acerca do significado de "au pair", responde: "Au pair significa trabalhar muito, prima, e não ganhar, quase, como se pertencêssemos à família" (BRAGA, 1986: 132).

\footnotetext{
${ }^{1}$ Este artigo foi produzido no âmbito do projecto MYRG2016-00004-FAH, financiado pela Universidade de Macau.
} 
É nesse sentido que, partindo dos conceitos de memória e identidade, analisaremos, primeiramente, o "álbum" de família da narradora, a forma como as suas origens são configuradas e as memórias selecionadas com o intuito de (re)construir ou (re)configurar a sua identidade, para depois abordar a sua relação com as famílias estrangeiras e o modo como a literatura se assume também como vector de construção do "eu".

Retratos de família: transmissão cultural e formação da identidade

Tal como afirmou Pierre Nora, "A memória é a vida, [...] e nesse sentido, ela está em permanente evolução, aberta à dialéctica da lembrança e do esquecimento [...] susceptível de longas latências e de repentinas revitalizaçôes" (1993: 9). Por conseguinte, é precisamente um acto de "revitalização" da memória que se assume como ponto de partida da obra Estátua de Sal de Maria Ondina Braga. A narradora revela, no início, que vive em Macau há três meses, salientando o poder deste espaço como impulsionador da rememoração e da autodescoberta: "Macau é a minha alma a revelar-se, é toda uma vida de exaltação e de mágoa analisada, revivida [...]” (BRAGA, 1969: 14). Por conseguinte, aquele momento de exílio numa terra tão distante desencadeia todo o processo rememorativo que estrutura a obra, já que, como declara ainda, "[...] acima de tudo, quero encontrar-me comigo. Acima de tudo, desejo recordar a minha terra, as pessoas e os lugares que amei, outros passos..." (BRAGA, 1969:14).

É, assim, através da evocação das pessoas amadas que podemos considerar que as memórias vão delineando na narrativa "álbuns" de família. E, neste ponto, importa aludir aos conceitos de memória colectiva e individual de Maurice Halbwachs, patentes na sua obra On collective Memory [ $A$ memória colectiva] (1992). Na verdade, embora Estátua de Sal se centre numa memória individual, interior ou pessoal, organizada em torno da protagonista-narradora, não podemos esquecer que essa memória individual se encontra sempre, segundo Halbwachs, interpenetrada pela memória colectiva, visto que são assimilados todos os contributos externos que acabam por se fundir com a dimensão individual, pois as memórias são reconstruídas sob a pressão da sociedade (HALBWACHS, 1992: 51). Este efeito externo é exercido na memória individual também, por vezes, através dos objectos que povoam o exíguo quarto onde vive a protagonista e que, como veremos mais adiante, de forma proustiana, desencadeiam o desfile de memórias. Como refere a autora: "Hoje, é o Sul da China. Outro tempo foi Inglaterra. As coisas, no entanto, é que me têm aguentado viva" (BRAGA, 1969: 41). Se a memória é delineada por experiências, configurada pelas vivências dos indivíduos e 
pelos grupos sociais onde se integram, o primeiro deles e o mais importante desde o início será indubitavelmente a família, espaço onde mergulham as raízes identitárias do "eu".

No "álbum de família" da narradora, encontramos, pois, "retratos", sobretudo dos pais, tios e irmã. Principiaremos, neste caso, pela configuração dos pais, já que, tal como refere Zilà Bernd, "falar dos pais é um subterfúgio para falar de si próprio" (2014: 18). Com efeito, a primeira alusão aos pais que encontramos na obra surge conectada com a questão da morte. Ao evocar o passado, a narradora seleciona os acontecimentos que se revestem de significado particular - processo selectivo a que Pollak denominou "enquadramento", já que implica que sejam selecionadas e enquadradas determinadas memórias transmitidas pela entidade narrativa (POLLAK, 1989: 8). Revela-se aí o primeiro contacto da protagonista com a morte, ocorrido através do falecimento do pai, e um episódio caricato vinculado a este acontecimento: o engano nas medidas do caixão. A selecção destas memórias reflecte o gosto pela efabulação a par de uma certa obsessão pela morte que transparece ao longo da sua obra:

O pai morreu tinha eu dez anos. Recordo-me de que erraram as medidas do corpo, o caixão ficou curto, esteve um dia inteiro na cama, vestido, pronto, fato preto, a cara muito branca, imperturbável. Quando me levaram a vê-lo, na manhã a escorrer prantos e cochichos pelo corredor, tinha os queixos atados num lenço, e as mãos que me fizeram beijar eram frias de mármore. Eu não sabia entáo que os mortos ficavam gelados e sofri um susto. A morte de que falavam as flores secas, os retratos e as suas histórias, tinha algo de romântico, era quase bela. A realidade, todavia, apresentava-se terrível. O corpo do pai estava enregelado. Desinfectava-se o quarto. Apressava-se o funeral. (BRAGA, 1969: 60)

A narradora revela, assim, uma discrepância entre uma ideia romântica, ficcionalizada e idealizada da morte e a brutal e gélida realidade com que se deparou no contacto físico com o cadáver do pai. Do mesmo modo, relativamente à mãe, também a primeira referência corresponde ao momento da morte: "Eu sonho muitas vezes com os mortos. Vejo-os belos, calados, tristes. Minha mãe morreu magrinha, de mal terrível. Lembro-a, no caixão, de cabelos grisalhos e face encovada. Mas, nos meus sonhos, ela surge nova e bonita. [...]" (BRAGA, 1969: 59). Deste modo, através da evocação da figura da mãe no caixão, a narradora parece querer reconstruir sua imagem, embelezando-a, através do "filtro" que só a passagem do tempo e a dimensão onírica podem possibilitar. No fundo, ela ainda recorda a terrível doença que vitimou a sua progenitora, mas "nos sonhos, ela surge nova e bonita". Como preconiza Halbwachs, o processo de recordaçáo do passado parte sempre da construção de uma experiência marcada pelos ideais e a maturidade do presente (1992: 
46). Além disso a memória familiar pressupóe, como afirma Anne Muxel, uma "negociação misteriosa do indivíduo consigo mesmo para reapropriar-se dos fragmentos do passado (MUXEL, 2007: 7). Será todo esse processo de amadurecimento e de confronto do "eu" consigo próprio que determina a fixação da imagem da mãe, correspondendo não a uma fase de decadência, mas tendo cristalizado a sua aparência ainda jovem e bela.

Além disso, a morte é enfatizada como tendo sido uma presença habitual ao longo da vida da narradora: "Habituei-me à ideia da morte desde pequena. [...] Contava-se da avó paterna escoando-se em sangue, de noite, as veias abertas" (BRAGA, 1969: 59). Assim, o verbo "contar" instala na narrativa a noção de transmissão de conhecimento e de memória familiar através da narrativa, como em seguida, abordaremos com mais detalhe. Para além do fenómeno da morte e das histórias relacionadas com ele, a morte assume-se também como o acontecimento agregador, que "reúne" a família, associado quase a um movimento diaspórico, comparado ao acto de emigrar que vai, aliás, marcar a vida da autora: "E vi depois os mais da casa irem passando, a pouco e pouco. Era como se toda uma família abandonasse o país natal rumo à terra da aventura, hoje estes, amanhã aqueles, com saudades uns dos outros" (BRAGA, 1969: 60). A seguir, intercalados com as diversas narrativas de outros episódios de vida da narradora, surgem-nos novamente os pais, através de constantes analepses, como se "ressuscitassem" no âmago da narrativa, num percurso narrativo inverso ao da vida real, apresentado sob uma perspectiva dominantemente intradiegética "Foi no último dia de um Agosto ardente que meu pai adoeceu de morte. Tinha-se feito compota de damasco e cheirava a açúcar por todo o lado" (BRAGA, 1969: 118). Nota-se, nesta citação, a evocação do cheiro como elemento intransmissível da memória - o que sucede com alguma frequência, pois as personagens e os espaços surgem associados a odores, que parecem contribuir para uma caracterização mais completa e verossímil. Isto porque o odor pertence a um plano da experiência individual, pois como afirma Muxel, a memória dos sonhos e dos cheiros é impossível de transmitir, apesar do seu poder de inscrição, daí os cheiros, à semelhança dos sons serem considerados como "arquivistas do efémero" (MUXEL, 2007). Neste caso, o poder evocativo do odor a açúcar da compota de damasco contrasta, de certo modo, com o episódio da doença grave do pai da protagonista, assumindo-se, apesar disso, como um elemento que acrescenta vivacidade e verosimilhança à recordação. Nesta esteira, como refere Tuan, "Odor has the power to evok vivid, emotionally-charged memories of past events and scenes" (1990: 10). ${ }^{2}$ Deste modo, as frequentes referências aos

\footnotetext{
2 "O odor tem o poder de evocar nítidas memórias carregadas de emoção de eventos e cenas passadas" (trad. nossa).
} 
odores presentes nas descrições contribuem para a transmissão de emoçôes efémeras e intensas, que conferem maior realismo e vida aos acontecimentos.

De um modo geral, para além dos episódios evocativos da vivência com os pais e tios, o conhecimento dos antepassados, dos familiares já falecidos e a transmissão da memória familiar são recebidos pela narradora por duas vias: através dos retratos presentes no sótão e de uma tradição oral, materializada pelas histórias contadas pela sua mãe à lareira. A descrição das imagens dos antepassados assemelha-se à de personagens irreais, pertencentes a um universo imaginário:

Nos baús, eram os retratos. Muito antigos, os das avós, bisavós, tios e tias da mãe. Eles de cartola e barbas. Elas de penteados altos, sérias, apertadas nos espartilhos. Eu tinha ouvido a história de cada um. Estavam todos mortos, mas era como se ressuscitassem ali, nas fotografias desbotadas, imprecisas. (BRAGA, 1969: 94)

Assim, ao contemplar os retratos dos antepassados, a narradora confere rosto aos protagonistas das histórias ouvidas e confere-lhes uma nova vida imaginada. Todos estes familiares parecem cristalizados nas fronteiras do tempo, como personagens de um romance.

Mais adiante, a personagem-narradora revela-nos o facto de a imagem do pai lhe invadir os sonhos e de a mãe vir rezar com ela, como modo de conforto e de garantia do eterno descanso do falecido. Aliás, o ambiente religioso e austero que marcava o contexto social da família da protagonista, em Braga, é evocado frequentemente: "Filha de Braga, cidade dos Arcebispos, a minha infância tinha de ser marcada de religiosidade" (BRAGA, 1969: 124). Essa religiosidade é utilizada igualmente para caracterizar a mãe: "Minha mãe era uma senhora de antigamente. Ia à missa às seis horas da manhã, nunca saía à rua em cabelo, criou os filhos com uma austeridade quase monacal" (BRAGA,1969: 177). A mãe é ainda descrita como "paciente e justa", sendo também a "voz" transmissora das histórias e memórias familiares que contava ao serão. Assume-se assim como guardiã de um passado veiculador de valores que, de outra forma, jazeria sepultado no poço do esquecimento: "Os nomes dos que tinham passado encaixilhados na memória a eterno. Um fio de mágoa na voz. A certeza de Deus" (BRAGA, 1969: 209). Desse modo, as narrativas da mãe assumiam-se como uma forma de manter vivos aqueles que já haviam perecido, eternizando-os.

Por seu turno, este tempo da infância, suspenso, cristalizado, configura-se para a narradora como um refúgio para se evadir do peso doloroso da existência presente. Então, como lenitivo para essa angústia, ecoam as histórias de aventuras verídicas cujos heróis eram os familiares:

Aquele tio-avô, três meses no mar num barco à vela, para chegar ao Brasil com doze anos, enriquecer, ser-lhe dado o título de visconde! A mãe da mãe contara. 
A mãe conhecera-o: corpo frágil, olhos claros, inteligência lúcida; uma mulher negra; uma mulher branca; vinte filhos; diabetes. (BRAGA, 1969: 209-210)

Em breves palavras, com expressóes aparentemente lançadas ao acaso, mas profundamente significativas, reconstrói-se a história de um homem corajoso, tenaz e persistente, um herói que, tendo partido com apenas doze anos num barco a vela, conseguiu enriquecer, obter um título de nobreza (visconde) e deixar uma enorme descendência. Transmite-se assim a importância de valores como a coragem, a persistência, lucidez e inteligência. Para aumentar o grau de verossimilhança, a narradora salienta que "a mãe conhecera-o", sublinhando uma atitude testemunhal. Nesta sequência, verificamos que na evocação destas histórias se evidenciam, à partida, as funçóes de transmissão e de revivescência afectiva (MUXEL, 2007: 13). Então, enquanto na primeira se verifica uma mobilização da memória como forma de restituição da história do indivíduo no âmago dos laços que o unem aos membros da família, a função de revivescência reveste-se de um teor profundamente afectivo, tentando manter os afectos, após a morte dos familiares, e colmatar, de certo modo, o seu desaparecimento (MUXEL, 2007: 14). É o que sucede com as mais diversas evocaçóes feitas pela narradora dos membros da sua família e também através da continuação da descrição das narrativas familiares transmitidas oralmente pela mãe:

Aquela tia louca aos trinta anos - irmá mais velha da mãe, literata, escrevia para os jornais.

Diante do lume que, como o do poeta inglês, erguia e desmoronava castelos de oiro, exércitos de sangue, cidades de sol e de lenda, a louca ressuscitava à voz da saudade fraternal, triste e linda, na janela de espera do proibido amante. Ele de capa à trovoador, o cavalo de patas entrapadas, a fidalguia nas veias. Amor impossível. Ela era filha do povo. Muito belos ambos. Muito infelizes os dois. [...] (BRAGA, 1969: 210).

A história da "tia louca" parece alertar para o perigo dos amores impossíveis, da quebra das convençóes sociais. Contudo, esta heroína romântica e infeliz desperta profundo interesse na narradora, que evidencia afinidades com ela, como é o caso do amor à literatura. Os ingredientes romanescos são evidentes, assim como os heróis românticos: um casal belo e infeliz, que vivencia um amor impossível, impedido pelas convençóes sociais - o que evoca, por exemplo, os protagonistas da obra Amor de Perdição de Camilo Castelo Branco.

A tia é ainda recordada através dos retratos: "A gente recordava a doida nos retratos das águas-furtadas. A mãe prosseguia: histerismo, defumadouros de bruxas, intrigas e crendices, dinheiro esbanjado, paixóes...Um romance inteiro de Camilo" (BRAGA, 1969: 210-211). Note-se que a referência ao escritor Camilo Castelo Branco é recorrente ao longo da obra, espelhando 
uma profunda admiração por este autor e assumindo-o como modelo e "memória" literária simultaneamente, ou, por outras palavras, um "familiar" do ponto de vista literário.

Além disso, a fixação escrita das histórias narradas pela mãe reveste-se de um teor meta-memorialista para a representação da memória familiar. Tal como preconiza Candau, a reapropriação de um passado familiar - aqui presente através destas histórias passadas da mãe para a filha - é sempre específica, já que o sentido que é atribuído pelo narrador aos acontecimentos recordados é singular, idiossincrático (CANDAU, 2008: 138). Para além da transmissão e da revivescência, encontramos também a função de reflexividade, correspondente a uma reavaliação da própria vida através da recuperação da memória. Os episódios recuperados, que parecem rasgar as fronteiras da realidade e pertencer ao mundo da literatura, serão, por isso, aqueles que se integram na idiossincrasia da narradora, na sua atração pelas letras, pela escrita e por autores, sobretudo do Romantismo, como é o caso de Camilo Castelo Branco. No fundo, literatura e memórias familiares mesclam-se constantemente, pois como refere a narradora: "Aos treze anos, as minhas relaçóes eram os artistas e escritores mortos. Pobre menina, quanto os amei" (BRAGA, 1969: 179). Por conseguinte, as descriçóes do ambiente familiar seleccionadas e apresentadas contribuem para justificar a personalidade solitária da narradora, uma "outsider" (BROOKSHAW, 2002: 98), e o facto de a literatura se ter convertido para ela no refúgio central do seu mundo de vivências, habitado por personagens invulgares, frequentemente desviadas das normas sociais.

Relativamente aos familiares, para além desta tia louca, encontram-se ainda frequentemente referências à tia Graça, uma senhora muito católica, mas algo excêntrica, que tomara a liderança da casa após o falecimento do pai da protagonista. Ela vivera vários anos no Brasil e, embora se recusasse a assistir a sessóes espíritas, "Falava, no entanto, do que acontecia no casarão da fazenda, coisas, do outro mundo: uma mão escrita na porta, de manhă, e toda a noite, no pátio, o estropear de um cavalo invisível" (BRAGA, 1969: 59-60). Esta tia austera, cuja lembrança se associava ao cheiro dos medicamentos, com quem a narradora partilhava o quarto durante o Inverno, "sabia histórias deste mundo e do outro" (BRAGA, 1969: 215). Tal facto parece alimentar a já fértil imaginação da narradora e a sua atração pelo misterioso e pelo sobrenatural - outra característica que transparece da obra de Maria Ondina Braga, sendo referida também em Passagem do Cabo (1994). Esse "sobrenatural" surge como sinónimo do inacessível, que ela busca numa ânsia de reconstruir as dimensões do seu próprio eu (BRAGA, 1994: 125).

Progressivamente, continua a delinear-se o processo de formação da identidade da narradora, entretecido pelas memórias e histórias familiares, de onde emerge, como figura tutelar, a imagem da mãe: 
Recordar a minha mãe é julgar-me a mim mesma sem indulgência. Como posso eu sofrer com os outros, comigo, com a vida, depois de ter tido "uma mãe assim?” Que mal me virá de qualquer lado, que ventos de desengano para me derrubarem, que desespero a estrangular-me, quando sou filha da própria fortaleza. (BRAGA, 1969: 209)

Deste modo, a narradora insinua que a força revelada pela mãe supostamente a talharia para ser alguém quase indestrutível. Ainda acerca da sua progenitora, salienta o facto de a austeridade de princípios e hábitos da mãe a terem impedido de se tornar vaidosa e a terem afastado (a ela e à irmã) de actividades mundanas, como os passeios com as colegas de liceu e idas ao cinema. A consequência desta privação de convívio e de vivência social é deste modo sentida: "Assim me fiz menina só, toda entregue ao mundo dos livros e das ideias" (BRAGA, 1969: 122). Ou ainda, como anteriormente afirmara: "A minha alma pertencia ao mundo calado do alheamento e da solidão" (BRAGA, 1969: 95). De novo, são enfatizados os factores que contribuíram para a formação da personalidade da narradora. Não obstante, sendo a identidade do "eu" sempre forjada em confronto com o "outro", num processo de articulação (LEERSSEN, 2007: 340), a entidade narrativa salienta também as características que distinguem a irmã, que desenvolveu um tipo de personalidade bem diferente, pois, um pouco mais velha do que ela, era "uma menina fina" (BRAGA, 1969: 119). Na noite em que o pai adoecera, a irmã acordara e ajudara a família, enquanto a narradora revela um nítido remorso por nem sequer ter despertado. Então, a irmã “[...]cresceu rapariguinha ajuizada, séria, desejosa de prestar serviços, de se entender com as pessoas grandes" (BRAGA, 1969: 122). Neste caso, o "retrato" psicológico da irmã corresponde ao de uma criança inteiramente integrada no mundo dos adultos, em perfeita consonância com aquilo que os outros esperavam dela, nunca desapontando esses horizontes de expectativas. Enquanto isso, a narradora vai selecionando alguns dos factos que contribuíram para a formação da sua personalidade actual, solitária, nostálgica, entregue à paixão da escrita e da leitura, ou por outras palavras, para a formação da sua identidade presente, já que, como refere Mariana J. Sousa, "Memória e identidade se juntam no discurso na medida em que ambas são construçóes discursivas. Ao narrar-se, o sujeito mobiliza seu arsenal de experiências; póe em ação tudo o que o constitui para construir uma narrativa de si e consolidar um novo Eu" (SOUZA, 2014: 116).

Definindo-se em relação ao "outro", no seio familiar, neste caso em relação à irmá, a narradora exerce o princípio da alteridade, revelando o modo como se começou a percepcionar como um ser autónomo, independente e distinto. Emergem, assim, as linhas delimitadoras da identidade do "eu", em 
constante evolução, ao longo de uma divisão, a partir do lugar do Outro" (HALL, 2011:112).

Retratos das famílias britânicas:

em demanda do sentido de pertença

Em Estátua de Sal, interpenetradas pelas memórias da sua família, emergem as memórias de duas famílias britânicas com as quais a autora viveu, na época em que trabalhou como au pair em Inglaterra. Se considerarmos, como preconiza Candau, que a memória familiar é simultaneamente a consciência de uma ligação e de uma separação (2008: 138), verificamos que estas noçóes se projectam nas famílias estrangeiras que a acolhem. Por um lado, há uma forte consciência de separação referente tanto à sua própria família, como a estas, por outro, constata-se também um fenómeno de ligação. De um modo geral, a narradora avalia a sua experiência como preceptora de crianças no estrangeiro de modo ambivalente, considerando que é algo que pode ser simultaneamente "aliciante e destruidor" (BRAGA, 1969: 107). E mais adiante explicita: "Penso mesmo que, se não tomássemos as crianças como objectos mais ou menos interessantes e os pais delas como se não existissem, se polidamente nos não revestíssemos da distância e do isolamento, deixaríamos de ser" (BRAGA, 1969: 107). Por outras palavras, a identidade da personagem correria o risco de se desvanecer e aniquilar nessa situaçáo laboral e vivencial tão particular.

A primeira família retratada é a dos Mills, com quem a narradora co-habitou em Worcester. Devemos, neste ponto, salientar que a referência a estas famílias de "empréstimo" surge na obra antes das alusôes à família da narradora. De certo modo, a imersão e observação das vivências e dos rituais destas famílias estrangeiras parecem servir como preparação para depois o "eu" mergulhar nas suas próprias raízes, como se os olhares sobre o "outro" se assumissem como um percurso preparatório para a reconstrução do passado mais íntimo e individual do "eu". A primeira memória apresentada dos Mills refere-se, pois, a uma visita feita a esta família, na época da Páscoa, associada a rituais importantes da cidade natal e da família da protagonista. Na alusão a esta quadra festiva verificamos o uso da analepse, pois as memórias não são organizadas em termos de cronologia temporal, sendo delineadas a partir de um acontecimento-chave, relevante no presente, que depois nos conduz a um conhecimento mais aprofundado ou a uma justificação desse mesmo evento:

Pensei que voltar a Worcestershire ia ser doloroso e bom, ao mesmo tempo. Não que tivesse saudades da Mrs. Mills, nem que me interessasse o sabonete embrulhado em papel de cor da oferta dos meninos. Mas apetecia-me rever as crianças e o campo, reaver o cheiro da província, o verde muito verde das 
pastagens, os talhóes do aipo, couve-roxa, couve-de-Bruxelas, perder-me na ilusão de infinito das estradas pela Primavera. (BRAGA, 1969: 23)

Neste caso, evidencia-se que o principal vínculo afectivo é com as crianças e a paisagem de Worcester. A ambivalência de sentimentos é notória, pois nota-se uma hesitação entre o desejo de usufruir da paisagem, dos "cheiros da província", de reaver as crianças, e, paralelamente, um certo desconforto. A narradora revela a comoçáo sentida ao rever as crianças, os seus "meninos de empréstimo" (BRAGA, 1969: 24): "James, de seis anos, muito branco e gordo, lembrava um Cupido de jaspe. Os seus braços à roda do meu pescoço - os pulsos quentes e húmidos na camisa escassa de mangas -, braços que me despenteavam, deliciosamente familiares" (1969: 24). Notamos um contraste entre a descrição elaborada do pequeno James, impregnada de ternura, como se substituísse do ponto de vista afectivo, o filho que a narradora nunca teve, e, por outro lado, o modo como é representada Mrs. Mills, personagem que provoca na narradora um "cansaço desmoralizador" (BRAGA, 1969: 25), pois sendo uma pessoa distante e calculista, era como se arrastasse

[...] um duro destino de morte, mas não a morte, que os fiéis, assistindo à Missa na Igreja, sempre me revelam. Esta é a do homem resignado à sua própria fraqueza diante de um Deus que pode tudo; aquela, a do homem afundado no caos de um mundo que ele mesmo, ousada e inutilmente, construíra (BRAGA, 1969: 25).

É então que a religiosidade que sempre impregnou a infância da narradora emerge na descrição de Mrs. Mills, que também surge vinculada a uma ideia de morte e de um caos que ela própria instaura no seu universo. Posteriormente, a narradora compara a Páscoa de Worcester com a da sua terra, pois nesta cidade estrangeira não encontra "o musicar dos sinos nem o aroma das lestras e do alecrim" da sua terra, embora houvesse "altos coros na catedral, e na igreja católica a Missa do domingo" fosse solene (BRAGA, 1969: 25).

A religiosidade é outra das componentes que atravessam a escrita de Maria Ondina Braga e à qual se encontram vinculados diversos fragmentos de memória que descreve. Um desses momentos religiosos evocados é a Semana Santa, tempo de "grande azáfama na velha casa porque era o tempo das limpezas gerais” (BRAGA, 1969: 124). A descrição desses rituais, numa óptica comparativa, assume-se como um modo de conferir coesão a memórias dispersas de uma identidade também dispersa pelo mundo e pelas circunstâncias da vida. Nesta esteira, como lembra Halbwachs, todo o tipo de ideias pode trazer-nos à mente recordaçóes da nossa família (1992: 61).

Nas lembranças da casa de Mrs. Mills em Worcester, destaca-se o poder dos objectos, como elementos de revivescência, de recuperação do passado, em 
espaços estrangeiros: "Em casa, os objectos a que nos habituamos de meninos, parte de nós, que nos trazem as pessoas amadas e quase são elas, passam-nos frequentemente despercebidos. Mas, fora de casa, só eles falam" (BRAGA, 1969: 41). Deste modo, o poder evocativo dos objectos assoma constantemente ao longo da narrativa, contribuindo para a configuração dos diversos "álbuns" de memórias. Longe de casa, são os objectos que evocam a presença dos outros, das memórias, pois, tal como refere Paul Ricoeur, as coisas e as pessoas, os encontros memoráveis, limitam-se a aparecer, reaparecem como sendo as mesmas, sendo rememoradas menos pela sua irrepetível singularidade do que pelo seu carácter emblemático (RICOEUR, 2000: 28). Um dos objectos investido de valor simbólico é a xícara usada pela narradora. Através de uma associação de ideias revelada pelo fluxo da memória, essa xícara transporta o "eu" até a casa paterna, onde a sua mãe doente tomava leite por uma xícara semelhante. $\mathrm{O}$ objecto fica assim personificado, assumindo-se como o elemento central que sobrevive ao tempo: "A xícara era ali a única coisa viva e as pessoas meros objectos decorativos" (BRAGA, 1969: 148).

Ao contrário do que sucedia na representação da sua família, as descriçôes da família Mills evidenciam um ambiente familiar marcado pela rotina e pela normalidade. Um dos dois espaços privilegiados é o play room -"um aposento ao mesmo tempo utilitário e recolhido que tanto servia de sala de jantar como de sala de música, de estudo ou de brinquedos" (BRAGA, 1969: 42), já que a mesa onde o pequeno James realizava os exercícios escolares era a mesma onde eram servidas as frugais e requintadas refeiçôes de família. Além disso, destaca-se o quarto verde-azul onde a narradora dormia e que lhe evocava a imagem de um aquário. E acrescentam-se algumas sensações, sabores, cores, como se através da recolha de breves instantes se procurasse recuperar esse passado: "os bolos humpty-dumpty para os anos das crianças, a folhagem encarnada, verde, castanha, que as suas mãos brancas e grossas compunham nos jarróes, aquelas conchas de porcelana azul, com mal-me-queres, ao centro da mesa de jantar" (BRAGA, 1969: 42). Estes breves momentos marcados por uma ideia de beleza transparecem das descrições, como se apenas eles merecessem ficar registados neste "álbum" de memórias, como é o caso do encanto secreto das beterrabas cozidas, que tinham a cor "do manto do senhor dos Passos" - símile em que novamente a religiosidade irrompe até para fazer ultrapassar a banal caracterização da cor das beterrabas. Esses efémeros momentos são descritos de forma breve e intensa: "Era o encontro com a beleza. Momentos em que o mundo se tornava cor, movimento, melodia. Horas transparentes de perfeição" (BRAGA, 1969: 42). É pois esta a "imagem-lembrança" que coroa emblematicamente as recordaçóes da família Mills. A casa estrangeira e os seus objectos evocam também as memórias da 
casa paterna. Aliás, a importância da casa como lugar privilegiado da memória reveste-se de um teor simbólico, adquirindo, como preconiza Bachelard, o valor de um verdadeiro cosmos, já que "todo o espaço verdadeiramente habitado traz a essência da noção de casa" (BACHELARD, 1974: 200).

A outra família descrita na obra é a dos Knowles, do norte da Escócia, Inverness, onde a narradora diz ter chegado numa manhã "clara e fria de Setembro" (BRAGA, 1969: 47). A senhora Knowles, "de idade à volta dos cinquenta, era de estatura mediana, branca, fina e coxeava" (BRAGA, 1969: 47) e, ao contrário, de Mrs. Mills, é concebida como uma pessoa amável, alguém que sofreu diversas vicissitudes na vida, tendo mantido a doçura. Por seu turno, ao contrário da casa dos Mills, esta casa é marcada por um certo desleixo, evidenciado por "cadeiras desconjuntadas, móveis mal polidos, e um cão idoso e ruivo que arrastava as orelhas pelas alcatifas" (BRAGA, 1969: 47). A narradora deixa transparecer uma particular simpatia pelo Reverendo Knowles, cuja primeira imagem surge durante um encontro à ceia: "Alto, de ombros arqueados, um tanto desajeitado, lia o 'Punch', servia os vegetais às comidas, como bom chefe de família britânico, e era o Deão da catedral de Inverness" (BRAGA, 1969: 47). Seguidamente, são ainda referidos os gémeos de doze anos cujos nomes "o pai, como bom pastor anglicano, rebuscara na Bíblia”. Com efeito, o "álbum” de família dos Knowles parece corresponder a um tempo marcado por recordaçôes e vivências tranquilas e harmoniosas para a narradora, sendo igualmente descritos a natureza e o ambiente das ruas de Inverness. De um modo geral, evidencia-se uma proximidade com esta família, o que não transparecia nas descriçôes da anterior. São referidos momentos de harmonia partilhada e de saudável convivência, que diferem de um certo distanciamento usado para retratar os Mills, como se a narradora enfim se sentisse integrada nesta família.

As descriçôes acerca do tempo passado com esta família referem as excursóes feitas com eles ao campo, aos sábados, na rulote, nas quais até Sam, o velho cão de água, participava. Assim, "[...], ao entardecer, enquanto acendia a fogueira do acampamento Mr. Knowles cantava uma canção estranha, ardentemente mística e primitiva, como um hino ao fogo" (BRAGA, 1969: 49). Estes momentos descritos espelham uma cumplicidade entre a narradora e a família, reflectida na imagem genesíaca e primitiva do "canto ao fogo", como se pertencessem a uma mesma tribo ancestral. As memórias selecionadas evidenciam harmonia, intimidade e o contacto próximo com a natureza que a protagonista valoriza. Parece que uma afinidade muito forte os une, como se partilhassem os valores e a comunhão de uma verdadeira família: "deitávamo-nos com os pequenos numa tenda, sob grossas mantas de xadrez, em cama de feno - e o odor bom da terra subia das palhas, ouvia-se ao longe 
o rodar do comboio que a mim me embalava em sonhos de viagens de volta-a-casa" (BRAGA, 1969: 50). Essa expressão "volta a casa" encerra, justamente, um sentido de pertença que se expande na descrição de uma cena quotidiana e banal, na qual Mrs. Knowles prepara o chá e Mr. Knowles enche o cachimbo, despertando na narradora um sentimento de felicidade: "E eu a interrogar-me por que razão gostava daquela gente e por que me sentia assim feliz. Facto, antes, raro comigo. Uma espécie de comunicação de felicidade, um perfume de hora distante" (BRAGA, 1969: 53). A intimidade presente nos mais simples gestos do quotidiano dos Knowles acende paisagens familiares comparadas a "Algo semelhante a não saber nada nem ter desejos. Quase como dormir. Quase como chorar" (BRAGA, 1969: 53).

Em suma, ao contrário do que sucedia no seio da família Mills, marcada pela pouca familiaridade, frieza e distância, com os Knowles a narradora revela ter atingido um estado de harmonia e intimidade, um sentido de pertença conotado com o vivenciado numa verdadeira família.

\section{Considerações finais}

Ao longo de Estátua de Sal, os álbuns de família vão sendo traçados fragmentariamente, como um mosaico de recordaçôes, pois, como referiu Pierre Nora, "porque é afectiva e mágica, a memória [...] se alimenta de lembranças vagas, telescópicas. Globais ou flutuantes, particulares ou simbólicas" (NORA, 1993: 9). Essas memórias enraízam-se no tempo da infância visto como uma mítica idade de ouro, vivida com certa liberdade, apesar do ambiente conservador e do peso da religiosidade, pois à frente da narradora existia "o mundo inteiro, um mundo maravilhoso, desconhecido, que se esperava explorar de extremo a extremo como nos romances de Júlio Verne" (BRAGA, 1969: 34-35).

Aliás, o papel da leitura e da literatura revela-se preponderante na configuração dos diversos álbuns de família, na relação com o outro e com o mundo, e "o feitiço dos livros" (BRAGA, 1969:179) transparece ao longo da narrativa. Esse tempo da infância é retratado sob a égide das descobertas, das "velharias do sótáo", dos retratos de família, dos mais variados tesouros.

Por outro lado, nesse reino recriado pelos filtros da memória, a morte revela-se quase omnipresente. Por isso, são os retratos do sótáo, aliados às histórias contadas pela mãe, que constroem e asseguram uma vida a todos os familiares que já partiram. Desses familiares, para além dos pais e da irmá, merecem maior ênfase, devido a uma maior afinidade, aqueles que se afastam da "normalidade", da banalidade quotidiana. Como refere Brookshaw, também aqui são as personagens que rompem as regras as preferidas da autora: loucos, marginais, artistas incompreendidos, entre outros (2002: 81). 
Assim, a narradora reconfigura a sua identidade no âmago de uma solidáo nascida na casa paterna e depois pelo mundo dispersa, o que a conduz a projectar as suas memórias familiares nas famílias britânicas com quem vive, como se procurasse através de um mecanismo de compensação reconstruir e reactualizar um mundo de afectos perdido. Deste modo, a construção destes arquivos, ou "álbuns metafóricos", assume-se como vector fulcral da reconstrução e reconfiguração da identidade do "eu", que insiste em olhar para trás como a mulher de Lot para se reencontrar e reconhecer, descobrir a sua essência interior, no momento em que vive num território longínquo e estrangeiro, asfixiada pela ambiência de Macau. É assim que afirma: "Este quarto sufoca-me, realmente, cela de monja para quem foi destinado a tendas ao luar. Nele ainda cabe, contudo, uma legião de antepassados, homens e mulheres do meu sangue que souberam amar, sofrer, viver, morrer" (BRAGA, 1969: 210-211).

A evocação dos antepassados funciona, pois, como lenitivo para a solidão, catarse para o isolamento. No fundo, as múltiplas imagens e retratos familiares arquivados neste "álbum" maior que é a escrita assumem-se como alicerces da reconfiguração identitária, para que o "eu" não se perca nem dissipe nos tortuosos labirintos do longínquo exílio, naquele "mundo remoto como que eterno" (BRAGA, 1969: 15). Por outras palavras, um fio de memórias semelhante ao fio de Ariadne capaz de a salvar de ser devorada pelos "Minotauros" do tempo, do esquecimento e da solidão.

\section{Referências}

ASSMANN, Jan. La mémoire culturelle: écriture, souvenir et imaginaire politique dans les civilisations antiques. Trad. Diane Meur. Paris: Flammarion, 2010.

BERND, Zilá. "Romance Memorial (ou Familiar) e Memória Cultural: a necessidade de transmitir em Um defeito de cor de Ana Maria Gonçalves", Organon, Porto Alegre, v. 29, n. 57, jul-dez. 2014: 15-27.

BACHELARD, Gaston. A poética do espaço. Trad. de Antônio da Costa Leal e Lídia do Valle Santos Leal. São Paulo: Abril Cultural, 1974.

BRAGA, Maria Ondina Estátua de sal. Lisboa: Sociedade de Expansão Cultural, 1969. . Lua de Sangue. Lisboa: Ediçóes Rolim, 1986. . Passagem do Cabo. Lisboa: Editorial Caminho, 1994.

BROOKSHAW, David. Perceptions of China in Modern Portuguese Literature. Border Gates: The Edwin Mellen Press, 2002.

CANDAU, Joel. Memoria e identidade. Trad. Eduardo Rinsi. Buenos Aires: Ediciones del Sol, 2008.

GAGO, Dora Maria Nunes. "No espelho da memória: Macau, lugar mítico de (re) construçáo da identidade na obra de Maria Ondina Braga", Acta Scientiarum, v. 38, n.1, Jan-Março de 2016, p. 1-9. 
HALBWACHS, Maurice. On collective memory. Edited, translated and with an introduction by Lewis A. Coser. Chicago and London: University of Chicago Press, 1992.

LEERSSEN, Joep. “Identity/Alterity/Hibridity”. In: BELLER, M. \& LEERSSEN, J. Imagology, the cultural construction and literary representation of characters. Amsterdam, New York: Rodopi, 2007: 335-341.

MUXEL, Anne. Individu et mémoire familiale. Paris: Hachette, 2007.

POLLAK, Michael. "Memórias, esquecimento, silêncio". Revista Estudos Históricos, Rio de Janeiro: Ed UFRJ, v. 2, n. 3, 1989: 3-15.

REIS, Carlos \& LOPES, Ana Cristina. Dicionário de Narratologia. Coimbra: Livraria Almedina, 1991.

RICOEUR, Paul. Mémoire, histoire, oubli. Paris: Ed. du Seuil, 2000.

NORA, Pierre. "Entre memória e história - a problemática dos lugares". Trad. Yara Aun Khoury, Revista Projecto História, São Paulo: PUC-SP, n. 10, dez. 1993: 7-27.

SOUSA, Mariana Jantsch. "A memória como matéria prima para uma identidade: apontamentos teóricos acerca das noções de memória e identidade”. Revista Graphos, v. 16, n. 1, 2014: 91-117.

TUAN, Yi.Fu. Topophilia, a study of environmental perception and values. New York: Columbia University Press, 1990.

Dora Nunes Gago é professora de Literatura no Departamento de Português da Universidade de Macau. Doutora em Línguas e Literaturas Românicas Comparadas pela Universidade Nueva de Lisboa.

E-mail: doragago@umac.mo

Recebido em: 14/05/2016

Aprovado em: 14/06/2016 